\title{
Cytochrome C
}

National Cancer Institute

\section{Source}

National Cancer Institute. Cytochrome C. NCI Thesaurus. Code C129851.

Cytochrome c (105 aa, $\sim 12 \mathrm{kDa}$ ) is encoded by the human CYCS gene. This protein is involved in the transfer of electrons between complex III and complex IV of the mitochondrial electron transport chain. 